\title{
ANALISIS PERBAIKAN KONDISI LINGKUNGAN KERJA TERHADAP BEBAN KERJA MENTAL
}

\author{
SRI RAHAYUNINGSIH \\ Jurusan Teknik Industri, Fakultas Teknologi Industri, Universitas Kadiri \\ Jl. Selomangleng No. 1, Kediri, Jawa Timur 64115 \\ Surel: sri.nuning@gmail.com
}

\begin{abstract}
ABSTRAK
Kondisi lingkungan kerja yang baik akan menunjang pekerja dalam melakukan kerja yang maksimal. Faktor-faktor seperti temperatur, kebisingan, dan vibrasi dapat meningkatkan tekanan psikologis pekerja dan memengaruhi kinerja pekerja. PR Rezeki Abadi merupakan perusahaan rokok yang menggunakan tenaga manusia dalam menjalankan produksinya mulai dari proses pencampuran bahan-bahan dasar (tembakau, saos dan cengkeh) sampai dengan proses finishing. Berdasarkan hasil pengukuran, temperatur dan tingkat kebisingan pada bagian pencampuran lebih tinggi dari kondisi normal sehingga operator di bagian pencampuran merasakan beban psikologis yang tinggi dan sering melakukan kesalahan pada proses pencampuran. Tujuan dalam penelitian ini adalah melakukan perbaikan kondisi lingkungan kerja di bagian pencampuran tembakau dan melakukan pengukuran beban kerja mental dengan metode SWAT untuk mengetahui pengaruh perbaikan kondisi lingkungan kerja tersebut. Berdasarkan hasil perbaikan kondisi lingkungan kerja dengan menambahkan blower dan penggunaan tutup telinga, didapatkan kondisi lingkungan kerja yang sesuai dengan standar yaitu temperatur $25-27^{\circ} \mathrm{C}$ dan tingkat kebisingan $75 d B$. Hasil pengukuran beban kerja dengan metode SWAT menunjukkan rata-rata skala beban kerja dibawah 40 sehingga beban kerja termasuk dalam kategori ringan setelah dilakukan perbaikan kondisi lingkungan kerja.
\end{abstract}

Kata kunci: beban kerja mental, lingkungan kerja, pengukuran subjektif, SWAT

\begin{abstract}
Good condition of environmental work will support workers in performing operations maximally. Factors e.g. temperature, noise, and vibration have contribution in increasing psychological distress and affect to worker's performance. $P R$ Rezeki Abadi is a cigarette manufacturer which utilizes manual power of workers for establishing production in the whole flow process, starting from mixing materials (tobacco, sauce, and clove) until finishing. In accordance with measurement results, temperature and noise of environmental condition in mixing process workplace is higher than normal level so operators in this workplace get high psychological distress and often do mistakes in terms of mixing process. This research aims to develop environmental work condition particularly in the mixing material workplace and measure mental workload by using SWAT in order to find out the influence of environmental work development. Based on the development of environmental work condition through additional blower and use of earplug, it is obtained that temperature and noise intensity emerge in proper level with normal condition at $25-27^{\circ} \mathrm{C}$ and $75 \mathrm{~dB}$. The result of workload measurement using SWAT method shows that workload in average is under 40 so in other words the workload after development can be categorized as low level.
\end{abstract}

Key words: mental workload, environmental work, subjective measurement, SWAT

\section{PENDAHULUAN}

Kondisi lingkungan kerja adalah semua keadaan yang terdapat di sekitar tempat kerja. Kondisi lingkungan kerja yang baik akan menunjang karyawan dalam melakukan kerja yang maksimal. Faktor-faktor seperti temperatur, kebisingan, vibrasi, dan ketenangan dapat secara langsung memengaruhi kinerja tugas ketika mereka bekerja, hal ini disebabkan beban tekanan psikologis pekerja yang meningkat. Beban 
tekanan psikologis mengacu pada kondisi-kondisi yang dapat menyebabkan terjadinya kebingungan, frustasi yang terkait dengan kinerja tugas, sehingga membuat penyelesaian tugas menjadi lebih sulit untuk dilaksanakan (Purwaningsih dan Sugiyanto, 2007) Tekanan psikologis yang semakin tinggi akan menyebabkan beban kerja mental yang dirasakan oleh pekerja semakin meningkat.

PR Rezeki Abadi merupakan perusahaan manufaktur dengan hasil produksi utama adalah rokok. Perusahaan ini menggunakan tenaga manusia sebagai operator utama dalam menjalankan proses produksi mulai dari proses pencampuran (blending) bahan-bahan dasar (tembakau, saos, dan cengkeh) sampai dengan proses finishing. Berdasarkan hasil pengukuran temperatur dan tingkat kebisingan pada bagian pencampuran, temperatur ruang kerja mencapai $33-36^{\circ} \mathrm{C}$ dan tingkat kebisingan mencapai $75 \mathrm{~dB}$. Hasil ini menunjukkan temperatur dan tingkat kebisingan lebih tinggi dari kondisi normal yaitu $24-27^{\circ} \mathrm{C}$ dan 50-60 dB. Kondisi lingkungan kerja yang kurang nyaman tersebut, memengaruhi beban pekerjaan yang dirasakan oleh operator di bagian pencampuran tembakau sehingga menyebabkan terjadinya kesalahan pada proses pencampuran dan menurunkan hasil produksi rokok.

Pengukuran beban kerja mental dapat dilakukan dengan dua cara yaitu pengukuran secara objektif dan subjektif. Pengukuran beban kerja mental secara subjektif merupakan teknik pengukuran yang paling banyak digunakan karena mempunyai tingkat validitas yang tinggi dan bersifat langsung dibandingkan dengan pengukuran lain (Simanjutak dan Situmorang, 2010). Menurut Widyanti dkk. (2010), salah satu metode pengukuran beban kerja mental secara subjektif yang banyak diaplikasikan di Indonesia adalah Subjective Workload Assessment Technique (SWAT). Dalam penerapannya, SWAT akan memberikan penskalaan subjektif yang sederhana dan mudah dilakukan untuk mengkuantitatifkan beban kerja dari aktivitas yang harus dilakukan oleh pekerja. Berdasarkan permasalahan yang dihadapi PR Rezeki Abadi, maka tujuan dalam penelitian ini adalah melakukan perbaikan kondisi lingkungan kerja di bagian pencampuran tembakau dan melakukan pengukuran beban kerja mental dengan metode SWAT untuk mengetahui pengaruh perbaikan kondisi lingkungan kerja tersebut.

\section{METODE PENELITIAN}

Tahapan-tahapan yang akan dilakukan dalam penelitian ini adalah:

\section{Pengumpulan Data}

Data-data yang dikumpulkan untuk menjawab permasalahan di bagian pencampuran tembakau PR Rezeki Abadi sebagai berikut:

a. Beban Kerja

Beban kerja operator akan diukur dengan metode Subjective Workload Assessment Technique (SWAT), di mana operator diminta untuk mengurutkan kartu SWAT yang berjumlah 27 kartu berdasarkan subjektivitas mereka.

b. Kondisi Lingkungan Kerja

Kondisi lingkungan kerja yang diamati adalah temperatur dan kebisingan, sehingga perlu dilakukan pengukuran untuk mengetahui kondisi lingkungan kerja di bagian pencampuran yang ada saat ini. Pengukuran temperatur dilakukan dengan menggunakan termometer dan kebisingan dengan menggunakan digital sound level meter.

2. Pengukuran Beban Kerja Mental Sebelum Perbaikan Kondisi Lingkungan kerja

Metode Subjective Workload Asessment Technique (SWAT) pertama kali dikembangkan oleh Reid et al. pada tahun 1989. Menurut Reid et al. (1989), metode SWAT akan menggambarkan sistem kerja sebagai model multi dimensional dari beban kerja, yang terdiri atas tiga dimensi atau faktor yaitu beban waktu (time load), beban mental (mental effort load), dan beban psikologis (psychological stress load). Time load menunjukkan jumlah waktu yang tersedia dalam perencanaan, pelaksanaan, dan monitoring tugas. Mental effort load adalah menduga atau 
memperkirakan seberapa banyak usaha mental dalam perencanaan yang diperlukan untuk melaksanakan suatu tugas. Psychological stress load adalah mengukur jumlah risiko, kebingungan, frustasi yang dihubungkan dengan performansi atau penampilan tugas. Masingmasing dimensi terdiri dari 3 tingkatan yaitu rendah, sedang, dan tinggi yang dinyatakan dengan rating 1 sampai 3 (Wignjosoebroto dan Zaini, 2003).

Pengukuran beban kerja mental pada operator di bagian pencampuran tembakau dengan metode SWAT memiliki 2 tahapan prosedur, yaitu tahap penskalaan (scale development) dan tahap pemberian nilai (event scoring). Langkah-langkah pada tahap penskalaan adalah sebagai berikut:

1. Memberikan penjelasan secara mendetail mengenai metode SWAT.

2. Meminta subjek dalam hal ini adalah operator di bagian pencampuran tembakau untuk mengurutkan kartu SWAT yang berjumlah 27 kombinasi tingkatan beban kerja mental dari urutan beban kerja terendah sampai dengan beban kerja tertinggi menurut intuisi dan preferensi mereka. Dalam pengurutan kartu tersebut tidak ada suatu aturan mana yang benar atau yang salah.

3. Hasil pengurutan kemudian ditransformasikan ke dalam sebuah skala beban kerja dengan range 0-100 dengan menggunakan bantuan software SWAT.

Tahap pemberian nilai terhadap pekerjaan merupakan tahap pemberian nilai terhadap beban kerja yang dialami oleh subjek berkaitan dengan aktivitas yang dilakukannya (Purwaningsih dan Sugiyanto, 2007). Langkah-langkah pada tahap penilaian adalah sebagai berikut:

1. Identifikasi elemen atau variasi pekerjaan yang dikerjakan operator pencampuran tembakau.

2. Semua operator memberikan penilaian pada tiga dimensi SWAT dengan menggunakan rating 1 sampai 3 (rendah, sedang, dan tinggi) untuk semua elemen atau variasi pekerjaan yang telah diidentifikasi sebelumnya.
3. Hasil penilaian dikonversi menjadi skala beban kerja yang telah dibuat pada tahap penskalaan.

4. Menentukan beban kerja masing-masing operator pada tiap elemen pekerjaan apakah dalam kategori ringan, sedang, atau berat. Menurut Simanjuntak dan Simatupang (2010), rating SWAT yang berada di nilai 40 kebawah, maka beban kerja dari orang tersebut dikategorikan rendah. Sedangkan apabila SWAT ratingnya berada pada nilai 41 sampai 60 , maka beban kerja dari orang tersebut berada pada level menengah atau sedang, dan apabila nilai SWAT rantingnya berada pada nilai 61 sampai 100, maka dapat dikatakan bahwa beban kerjanya tinggi.

\section{Perbaikan Kondisi Lingkungan Kerja}

Berdasarkan hasil pengukuran kondisi lingkungan kerja dan standard lingkungan kerja yang nyaman akan diusulkan perbaikan kondisi lingkungan kerja di bagian pencampuran tembakau agar operator lebih nyaman dalam bekerja sehingga mengurangi stres dan beban psikologis.

\section{Pengukuran Beban Kerja Mental Setelah Perancangan Lingkungan Kerja}

Perbaikan yang diusulkan selanjutnya diimplementasikan pada bagian pencampuran tembakau PR Rezeki Abadi. Setelah implementasi dalam beberapa minggu, tiap operator diminta memberikan skor SWAT pada tiap elemen pekerjaan berdasarkan apa yang dirasakan dengan kondisi lingkungan kerja yang baru. Hasil penilaian skor SWAT tersebut kemudian digunakan untuk menentukan beban kerja mental setelah perbaikan kondisi lingkungan kerja.

\section{Perbandingan Beban Kerja Mental Berdasarkan Perbaikan Kondisi Lingkungan Kerja}

Langkah selanjutnya adalah membandingkan hasil pengukuran beban kerja mental sebelum dan sesudah perbaikan kondisi lingkungan kerja. Jika 
beban kerja mental operator sesudah perbaikan masih berada dalam level berat maka tahapan penelitian akan kembali pada perancangan kondisi lingkungan kerja. Sebaliknya jika beban kerja mental operator sesudah perbaikan berada dalam level ringan maka akan dilanjutkan pada analisis dan penarikan kesimpulan.

\section{HASIL DAN PEMBAHASAN}

\section{Pengukuran Beban kerja Mental dengan Metode SWAT pada kondisi lingkungan kerja saat ini.}

Pengumpulan data dengan menyebarkan kuesioner kepada 3 responden, yaitu operator pada bagian pencampuran tembakau. Pemakaian kartu-kartu kombinasi beban kerja mental, yaitu berupa lembaran yang dibuat secara khusus untuk mendukung pelaksanaan pengumpulan data. Setelah itu responden diminta untuk mengurutkan kartu-kartu tersebut berdasarkan persepsi masing-masing tentang tingkatan beban kerja dari yang paling rendah sampai paling tinggi. Kartu yang diurutkan berjumlah 27 buah, masing-masing merupakan kombinasi tingkatan dari ketiga dimensi SWAT. Sebagai contoh untuk kartu $\mathrm{N}$ terdiri dari kombinasi beban kerja 111, yang berarti berisi beban waktu $(\mathrm{T})$ rendah, beban usaha mental (E) rendah, dan beban tekanan psikologis rendah. Sedangkan kartu B terdiri dari kombinasi beban kerja 112, yang berarti berisi beban waktu ( $\mathrm{T}$ ) rendah, beban usaha mental (E) rendah, dan beban tekanan psikologis (S) menengah. Hasil pengurutan kartu SWAT keseluruhan dapat dilihat pada Tabel 1. Selain itu, operator diminta untuk memberikan penilaian SWAT pada tiap elemen pekerjaan pencampuran tembakau dan hasilnya ditunjukkan pada Tabel 2 .

Hasil pengurutan kartu kemudian diinputkan ke dalam software SWAT. Input data diuji validitasnya oleh software dengan uji Konkordansi Kendall untuk menghasilkan Kendall's Coefficient of Concordance (Koefisien kesepakatan Kendall). Jika nilai koefisien $\geq 0,75$ maka dapat dikatakan bahwa indeks kesepakatan dalam penyusunan kartu di antara pekerja relatif sama dan homogen. Dengan demikian lebih baik digunakan Group Scalling Solution (GSS). Sebaliknya jika nilai koefisien $<0,75$ maka dibutuhkan skala akhir yang terpisah, baik berdasarkan Prototyped Scalling Solution (PSS)

Tabel 1. Urutan Kartu SWAT Berdasarkan Preferensi Operator di Bagian Pencampuran Tembakau

\begin{tabular}{|c|c|c|c|c|c|c|c|c|c|c|c|c|c|c|}
\hline \multirow[b]{2}{*}{ Operator } & \multicolumn{14}{|c|}{ Tingkat Huruf dan Nomor } \\
\hline & 111 & 112 & 113 & 121 & 122 & 123 & 131 & 132 & 133 & 211 & 212 & 213 & 221 & 222 \\
\hline & $\mathrm{N}$ & B & W & $\mathrm{F}$ & $\mathrm{J}$ & $\mathrm{C}$ & $X$ & $\mathrm{~S}$ & $\mathrm{M}$ & $\mathrm{U}$ & $\mathrm{G}$ & $\mathrm{Z}$ & V & $\mathrm{Q}$ \\
\hline Jen & 2 & 3 & 5 & 8 & 11 & 18 & 1 & 6 & 12 & 13 & 4 & 19 & 14 & 10 \\
\hline Heri & 1 & 2 & 3 & 8 & 7 & 24 & 12 & 13 & 14 & 17 & 6 & 6 & 9 & 5 \\
\hline \multirow[t]{2}{*}{ Agung } & 27 & 1 & 5 & 8 & 9 & 10 & 12 & 17 & 18 & 2 & 6 & 25 & 11 & 13 \\
\hline & \multicolumn{14}{|c|}{ Tingkat Huruf dan Nomor } \\
\hline \multirow[t]{2}{*}{ Operator } & 223 & 231 & 232 & 233 & 311 & 312 & 313 & 321 & 322 & 323 & 331 & 332 & 3 & 33 \\
\hline & $\mathrm{ZZ}$ & $\mathrm{K}$ & $\mathrm{E}$ & $\mathrm{R}$ & $\mathrm{H}$ & $\mathrm{P}$ & $\mathrm{D}$ & $\mathrm{Y}$ & $\mathrm{A}$ & $\mathrm{O}$ & $\mathrm{L}$ & $\mathrm{T}$ & & \\
\hline Jen & 7 & 20 & 21 & 15 & 22 & 25 & 9 & 23 & 16 & 24 & 17 & 27 & & 6 \\
\hline Heri & 10 & 15 & 11 & 16 & 19 & 22 & 25 & 23 & 18 & 21 & 26 & 20 & & 7 \\
\hline Agung & 14 & 19 & 3 & 7 & 24 & 15 & 16 & 21 & 22 & 4 & 20 & 23 & & 6 \\
\hline
\end{tabular}

Tabel 2. Skor SWAT yang Diberikan oleh Operator pada Kondisi Awal Lingkungan Kerja

\begin{tabular}{lccc}
\hline \multicolumn{1}{c}{ Deskripsi Pekerjaan } & $\begin{array}{c}\text { Operator 1 } \\
\text { (Jen) }\end{array}$ & $\begin{array}{c}\text { Operator 2 } \\
\text { (Heri) }\end{array}$ & $\begin{array}{c}\text { Operator 3 } \\
\text { (Agung) }\end{array}$ \\
\hline $\begin{array}{l}\text { Proses di mana dimulainya pencampuran } \\
\text { komposisi tembakau serta penyemprotan saos }\end{array}$ & 321 & 311 & 321 \\
Pencampuran komposisi cengkeh & 311 & 312 & 322 \\
\hline
\end{tabular}


Tabel 3. Nilai Prototype dari Tiap Operator

\begin{tabular}{lccccccc}
\hline \multicolumn{1}{c}{ Operator } & TES & TSE & ETS & EST & SET & STE & Prototipe \\
\hline Jen & 0,76 & 0,73 & 0,47 & 0,34 & 0,24 & 0,33 & T \\
Feri & 0,75 & 0,70 & 0,52 & 0,39 & 0,25 & 0,32 & T \\
Agung & 0,38 & 0,33 & 0,24 & 0,14 & 0,02 & 0,03 & T \\
\hline
\end{tabular}

Tabel 4. Nilai Skala Akhir SWAT

\begin{tabular}{rccccc}
\hline No & $\begin{array}{c}\text { Kombinasi beban } \\
\text { kerja }\end{array}$ & Huruf & $\begin{array}{c}\text { Skala akhir } \\
\text { Operator 1 }\end{array}$ & $\begin{array}{c}\text { Skala akhir } \\
\text { Operator 2 }\end{array}$ & $\begin{array}{c}\text { Skala akhir } \\
\text { Operator 3 }\end{array}$ \\
\hline 1 & 111 & N & 0 & 17,8 & 57,8 \\
2 & 112 & B & 4,3 & 11,8 & 47,5 \\
3 & 113 & W & 13 & 31,4 & 45,9 \\
4 & 121 & F & 23,9 & 28,1 & 32,3 \\
5 & 122 & J & 28,2 & 22 & 22,1 \\
6 & 123 & C & 37 & 41,6 & 20,5 \\
7 & 131 & X & 24,6 & 18,6 & 64,6 \\
8 & 132 & S & 28,9 & 12,5 & 54,4 \\
9 & 133 & M & 37,7 & 32,1 & 52,8 \\
10 & 211 & U & 29,2 & 6,1 & 37,3 \\
11 & 212 & G & 33,5 & 0 & 27 \\
12 & 213 & Z & 42,2 & 19,6 & 25,4 \\
13 & 221 & V & 53,1 & 16,3 & 11,8 \\
14 & 222 & Q & 57,4 & 10,3 & 1,6 \\
15 & 223 & ZZ & 66,2 & 29,9 & 0 \\
16 & 231 & K & 53,8 & 6,8 & 44,1 \\
17 & 232 & E & 58,1 & 7 & 33,9 \\
18 & 233 & $\mathrm{R}$ & 66,9 & 20,3 & 32,2 \\
19 & 311 & $\mathrm{H}$ & 62,3 & 76,2 & 93,2 \\
20 & 312 & $\mathrm{P}$ & 66,6 & 70,1 & 83 \\
21 & 313 & $\mathrm{D}$ & 75,4 & 89,7 & 81,3 \\
22 & 321 & $\mathrm{Y}$ & 86,2 & 86,5 & 67,8 \\
23 & 322 & $\mathrm{~A}$ & 90,5 & 80,4 & 57,5 \\
24 & 323 & $\mathrm{O}$ & 99,3 & 100 & 55,9 \\
25 & 331 & $\mathrm{~L}$ & 87 & 76,9 & 100 \\
26 & 332 & $\mathrm{~T}$ & 91,2 & 70,9 & 89,8 \\
27 & 333 & $\mathrm{I}$ & 100 & 90,5 & 88,2 \\
\hline & & & & & \\
\hline
\end{tabular}

atau Individual Scalling Solution (ISS). Koefisien Kendall yang diperoleh sebesar 0,6239, nilai ini lebih kecil dari 0,75 yang artinya data terlalu heterogen dan pengukuran beban kerja mental akan dilakukan per operator.

Nilai prototype menunjukkan dimensi yang dominan dirasakan sebagai beban mental oleh responden. Hasil pengolahan data menunjukkan prototype dari tiap-tiap operator termasuk dalam Time (Tabel 3), maksudnya pekerja tersebut menganggap beban waktu merupakan dimensi yang relatif yang paling penting dibandingkan dengan dua dimensi lainnya. Nilai kepentingan untuk setiap faktor adalah Faktor $\mathrm{T}$ (waktu) $=$ $65,1 \%$, faktor $\mathrm{E}$ (usaha mental) $=21,13 \%$, dan faktor $\mathrm{S}$ (stress) $=13,77 \%$. Skala akhir tiap operator yang diolah menggunakan software SWAT dapat dilihat pada Tabel 4. Setelah skala akhir SWAT diperoleh maka dilakukan event scoring untuk mengetahui beban kerja mental, yaitu dengan cara mengkonversikan penilaian SWAT pada Tabel 2 dengan skala akhir tersebut.

Sebagai contoh pada Tabel 2, operator 1 memberikan rating beban 311 pada pekerjaan 
Tabel 5. Hasil Pengukuran Beban Kerja Mental pada Kondisi Awal Lingkungan Kerja

\begin{tabular}{lccccc}
\hline \multirow{2}{*}{ Deskripsi Pekerjaan } & \multicolumn{7}{c}{ Konversi ke Skala Akhir SWAT } & & \\
\cline { 2 - 6 } & Operator & Operator & Operator & Total & Rata-Rata \\
\hline $\begin{array}{l}\text { Proses di mana dimulainya } \\
\text { pencampuran komposisi }\end{array}$ & 86,2 & 76,2 & 67,8 & 230,2 & 76,73 \\
$\begin{array}{l}\text { tembakau serta penyemprotan saos } \\
\text { Pencampuran komposisi cengkeh }\end{array}$ & 62,3 & 70,1 & 57,5 & 189,9 & 63,3 \\
\hline
\end{tabular}

pencampuran komposisi cengkeh, sehingga skala beban kerja langsung dapat dilihat pada Tabel 4 sebesar 62,3. Hasil rata-rata penilaian beban kerja dari ketiga operator pada kondisi lingkungan yang ada sekarang ditunjukkan pada Tabel 5.

Dari Tabel 5 diperoleh rata-rata skala akhir untuk ketiga operator di bagian pencampuran sebesar 76,773 (berada di antara 61-100) untuk kedua jenis pekerjaan yang ada sehingga disimpulkan bahwa beban kerja yang dirasakan oleh operator berada dalam kategori berat. Berdasarkan pengukuran kerja tersebut maka perlu dilakukan upaya-upaya untuk mengurangi beban kerja mental yang dirasakan operator, salah satunya adalah memperbaiki kondisi lingkungan kerja di bagian pencampuran tembakau.

\section{Usulan Perbaikan Kondisi lingkungan Kerja}

Berdasarkan pengukuran temperatur kondisi awal lingkungan kerja di bagian pencampuran tembakau didapatkan temperatur ruangan sebesar $33-36^{\circ} \mathrm{C}$, temperatur yang tinggi tersebut menyebabkan konsentrasi pekerjaan kurang terfokus karena tubuh merasa tidak nyaman dan operator mudah merasa lelah sehingga operator merasa terbebani oleh pekerjaannya. Berdasarkan pengukuran awal lingkungan kerja bahwa tingkat kebisingan pada ruangan pencampuran tembakau sebesar $75 \mathrm{~dB}$, hal ini berarti tingkat kebisingan berada diatas batas normal kebisingan yaitu 60-70 dB. Pada batas dengar cukup tinggi dapat mengakibatkan hilangnya daya pendengaran.

Perbaikan kondisi lingkungan kerja dengan cara penambahan blower di ruangan pencampuran tembakau maka temperatur ruang mengalami penurunan yaitu sebesar $25,5-26,5^{\circ} \mathrm{C}$. Hal ini disebabkan sirkulasi udara di dalam ruangan pencampuran tembakau telah berjalan dengan baik. Hasil pengukuran tersebut menunjukkan bahwa temperatur pada ruangan pencampuran telah sesuai dengan standar temperatur yang normal dan operator merasa nyaman dalam bekerja. Sedangkan untuk mengurangi kebisingan pada operator pencampuran tembakau dilakukan dengan memberikan penutup telinga (ear plug), sehingga operator dapat merasa lebih nyaman dalam melakukan pekerjaannya.

Kondisi lingkungan kerja sebelum perbaikan tidak sesuai dengan standar temperatur dan kebisingan yang nyaman untuk operator dalam melakukan pekerjaannya. Setelah itu dilakukan perbaikan agar operator dapat bekerja dengan nyaman. Pada Tabel 6 dapat dilihat perbandingan kondisi lingkungan kerja sebelum dan sesudah perbaikan kondisi lingkungan kerja.

Tabel 6. Perbandingan Kondisi Lingkungan Kerja Sebelum dan Sesudah Perbaikan

\begin{tabular}{lcc}
\hline $\begin{array}{c}\text { Komponen } \\
\text { Lingkungan } \\
\text { Kerja }\end{array}$ & Sebelum & Sesudah \\
\hline Temperatur & $33-36^{\circ} \mathrm{C}$ & $25,5-26,5^{\circ} \mathrm{C}$ \\
Kebisingan & $75 \mathrm{~dB}$ & $75 \mathrm{~dB}$ \\
\hline
\end{tabular}

\section{Pengukuran Beban Kerja Mental Sesudah Perbaikan Lingkungan Kerja}

Hasil implementasi perbaikan kondisi lingkungan kerja dengan menambahkan blower dan pemakaian tutup telinga bagi operator di bagian pencampuran tembakau akan dievaluasi 
Tabel 7. Skor SWAT yang Diberikan oleh Operator Setelah Perbaikan Kondisi Lingkungan Kerja

\begin{tabular}{lccc}
\hline \multicolumn{1}{c}{ Deskripsi Pekerjaan } & $\begin{array}{c}\text { Operator 1 } \\
\text { (Jen) }\end{array}$ & $\begin{array}{c}\text { Operator 2 } \\
\text { (Heri) }\end{array}$ & $\begin{array}{c}\text { Operator 3 } \\
\text { (Agung) }\end{array}$ \\
\hline $\begin{array}{l}\text { Proses di mana dimulainya pencampuran komposisi } \\
\text { tembakau serta penyemprotan saos }\end{array}$ & 123 & 113 & 121 \\
Pencampuran komposisi cengkeh & 131 & 121 & 212 \\
\hline
\end{tabular}

Tabel 8. Hasil Pengukuran Beban Kerja Mental

\begin{tabular}{|c|c|c|c|c|c|}
\hline \multirow{2}{*}{ Deskripsi Pekerjaan } & \multicolumn{3}{|c|}{ Konversi ke Skala Akhir SWAT } & \multirow{2}{*}{ Total } & \multirow{2}{*}{$\begin{array}{l}\text { Rata- } \\
\text { Rata }\end{array}$} \\
\hline & Operator 1 & Operator 2 & Operator 3 & & \\
\hline $\begin{array}{l}\text { Proses di mana dimulainya } \\
\text { pencampuran komposisi } \\
\text { tembakau serta penyemprotan saos }\end{array}$ & 37 & 31,4 & 32,3 & 100,7 & 33,56 \\
\hline Pencampuran komposisi cengkeh & 24,6 & 28,1 & 27 & 79,7 & 26,56 \\
\hline
\end{tabular}

untuk melihat apakah beban kerja yang dirasakan oleh operator telah berkurang. Ketiga operator kembali diminta untuk memberikan penilaian atau skor pada masing-masing elemen pekerjaan di bagian pencampuran seperti dapat dilihat pada Tabel 7.

Hasil konversi penilaian SWAT pada Tabel 7 dengan skala beban kerja yang diperoleh melalui tahap penskalaan pada Tabel 4 ditunjukkan pada Tabel 8. Setiap operator mempunyai beban kerja dibawah 40 pada keseluruhan elemen pekerjaan yang dilakukan, sehingga tiap operator merasa tidak terbebani dan pekerjaannya maksimal setelah kondisi lingkungan kerja yang diperbaiki. Tabel 8 menunjukkan ratarata beban kerja ketiga operator sebesar 33,56 untuk pencampuran komposisi tembakau dan 22,56 untuk pencampuran komposisi cengkeh. Kesimpulan yang dapat diperoleh adalah beban kerja tiap operator berada dalam kategori ringan untuk kedua elemen pekerjaan yang ada.

\section{PERBANDINGAN HASIL PENGUKURAN BEBAN KERJA MENTAL}

Perbandingan hasil pengukuran beban kerja sebelum dan sesudah perbaikan lingkungan kerja dengan metode SWAT dapat dilihat dari Tabel 5 dan 8. Setelah dilakukan perbaikan kondisi lingkungan kerja, beban kerja setiap operator mengalami penurunan dari kategori berat menjadi ringan pada kedua elemen pekerjaan yang ada. Pada elemen pekerjaan pencampuran komposisi tembakau, rata-rata skala beban kerja sebesar 76,733 pada kondisi awal lingkungan kerja dan sebesar 33,56 setelah dilakukan perbaikan kondisi lingkungan kerja atau dengan kata lain terjadi penurunan beban kerja sebesar 76,29\%. Elemen pekerjaan berikutnya di bagian pencampuran adalah pencampuran komposisi cengkeh. Hasil pengukuran beban kerja dengan metode SWAT memberikan skala sebesar 63,3 pada kondisi awal dan 26,56 setelah dilakukan perbaikan kerja atau dengan kata lain terjadi penurunan beban kerja sebesar $62,88 \%$.

\section{SIMPULAN}

Kondisi lingkungan kerja menjadi lebih baik dan lebih nyaman dengan adanya penambahan blower dan penggunaan earplug (penutup telinga) sehingga dapat menurunkan beban kerja operator di bagian pencampuran tembakau PR Rezeki Abadi. Berdasarkan pengukuran beban kerja dengan metode SWAT, rata-rata beban kerja operator pencampuran tembakau sebelum dilakukan perbaikan kondisi lingkungan kerja termasuk dalam kategori berat. Setelah dilakukan perbaikan kondisi lingkungan kerja, rata-rata skala beban kerja di bawah 40 sehingga beban kerja termasuk dalam kategori ringan. 


\section{DAFTAR PUSTAKA}

Purwaningsih, R., dan Sugianto, A., 2007. Analisis Beban Kerja Mental Dosen Teknik Industri Undip dengan Metode Subjective Workload Assesment Technique (SWAT), J@TI Undip, II (2), 28-39.

Reid, G.B., Potter, S.S., and Bressler, J.R., 1989, Subjective Workload Assessment Technique (SWAT): A User's Guide (U), Interim Report, Harry G. Armstrong Aerospace Medical Research Laboratory, Human System Division Air Force System Command Wright-Patterson Air Force Base, Ohio.
Simanjutak, R.A., dan Situmorang, D.A., 2010. Analisis Pengaruh Shift Kerja Terhadap Beban Kerja dengan Metode Subjective Workload Assesment Technique (SWAT), Jurnal Teknologi, 3 (1), 5360.

Widyanti, A., Johnson A., dan De Waard, D., 2010. Pengukuran Beban Kerja Mental dalam Searching Task dengan Metode Rating Scale Mental Effort (RSME), J@TI Undip, V (1),

Wignjosoebroto, S. dan Zaini, P., 2003, Studi Ergonomi Kognitif untuk beban Kerja Mental Pilot dalam Pelaksanaan Prosedur Pengendalian Pesawat dengan Metode SWAT, Jurnal Ilmiah Sains dan Teknologi ITS, 2 (2). 